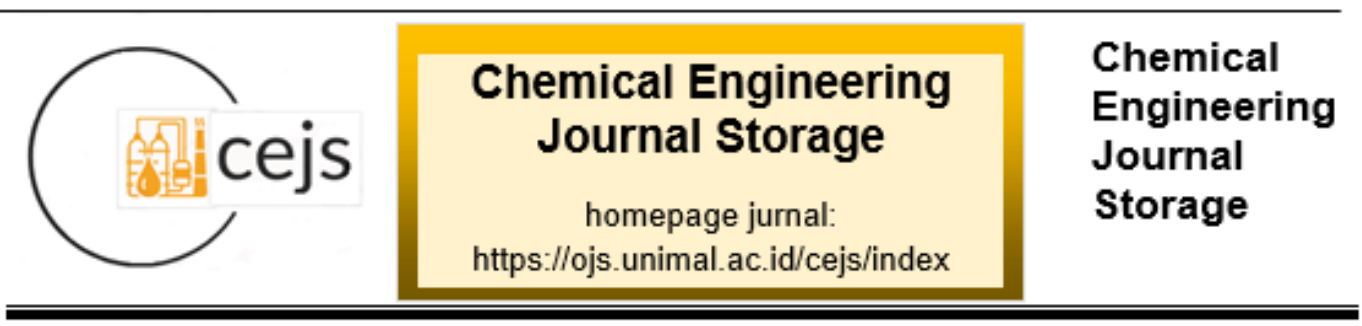

\title{
PENGARUH SUHU DAN WAKTU HIDROLISIS TERHADAP KADAR GLUKOSA DALAM PEMBUATAN SIRUP GLUKOSA DARI BIJI ALPUKAT DENGAN METODE HIDROLISIS ASAM
}

\author{
Mahaziva Putri Maghfirah Tambunan, Zainuddin Ginting*, Rizka Nurlaila \\ Jurusan Teknik Kimia, Fakultas Teknik, Universitas Malikussaleh \\ Kampus Utama Cot Teungku Nie Reuleut, Muara Batu, Aceh Utara - 24355 \\ Korespondensi: 0811676666, e-mail: zginting@unimal.ac.id
}

\begin{abstract}
Abstrak
Sirup glukosa dapat digunakan sebagai bahan baku industri makanan, minuman dan farmasi. Sirup glukosa dapat diperoleh dari bahan-bahan berpati seperti biji nangka, rebung, jagung, tapioka dan jenis umbi-umbian. Pemanfaatan limbah biji alpukat di Indonesia saat ini masih sangat minim, sehingga perlu dikembangkan lebih lanjut. Salah satunya dengan melakukan penelitian pembuatan sirup glukosa dari biji alpukat. Tujuan dari penelitian ini ialah untuk mengetahui pengaruh suhu dan waktu hidrolisi terhadap kadar glukosa dari biji alpukat dengan metode hidrolisis. Adapun proses yang digunakan dalam penelitian ini yaitu proses hidrolisis dengan katalisator $\mathrm{HCl}$ (asam klorida). Tahapan proses diawali dengan pembutaan tepung biji alpukat yang dilanjutkan dengan proses hidrolisis. Hidrolisis dilakukan di dalam labu leher tiga dengan penambahan asam klorida 3\% sebanyak $150 \mathrm{ml}$, dipanaskan dengan variasi suhu 75, 85 dan $95^{\circ} \mathrm{C}$ dan dengan variasi waktu 120, 135, 150, 165 dan 180 menit. Produk yang dihasilkan kemudian dianalisa kadar glukosa, kadar air, kadar abu dan analisa keadaan yang meliputi kadar kemanisan, warna dan bau. Hasil penelitian yang didapat dari penelitian ini yaitu suhu dan waktu sangat mempengaruhi kadar glukosa. Kadar glukosa paling tinggi yang didapatkan sebesar 50\% pada suhu $95^{\circ} \mathrm{C}$ dan waktu 180 menit. Kadar air paling baik yang diperoleh sebesar $17,4105 \%$ pada suhu $95^{\circ} \mathrm{C}$ dan waktu 180 menit. Kadar abu paling baik yang didapatkan yaitu sebesar 0,864\% pada suhu $95^{\circ} \mathrm{C}$ dan waktu 180 menit.
\end{abstract}

Kata kunci: Hidrolisis, Waktu, Suhu, Kadar Glukosa, Sirup Glukosa

\section{Pendahuluan}

Gula merupakan salah satu kebutuhan pangan pokok dalam kehidupan sehari-hari. Gula digunakan hampir dalam semua produk pangan baik itu pada makanan ringan maupun pada berbagai jenis masakan karena gula dapat memberikan rasa manis pada produk akhir. Indonesia merupakan pengimpor gula 
nomor dua terbesar di dunia. Kebutuhan gula di Indonesia semakin meningkat seiring dengan meningkatnya pendapatan per kapita dan jumlah penduduk. Menurut catatan Badan Litbang Pertanian, produksi gula nasional pada tahun 2011 mencapai 2.228.591 ton, sedangkan perkiraan produksi gula pada tahun 2012 akan mencapai 2.683.709 ton. Berdasarkan roadmap swasembada gula, kebutuhan gula nasional pada tahun 2014 sebesar 2.956.000 ton (Jonathan Giovanni, F. Sinung Pranata, 2013). Kebutuhan gula di Indonesia meningkat setiap tahunnya, maka produksi gula juga harus ditingkatkan.

Tingginya angka impor dan kebutuhan gula dalam negeri membutuhkan solusi. Salah satunya adalah dengan menggantikan gula pasir sebagai sumber glukosa dengan pemanis alternatif. Sumber alternatif pemanis non tebu dapat berasal dari pati. Gula pati tersebut mempunyai rasa dan tingkat kemanisan yang hampir sama dengan gula tebu (sukrosa).

Alpukat (Persea Americana Mill) merupakan salah satu jenis buah yang dapat tumbuh di tempat yang memiliki ketinggian dan curah hujan bervariasi. Buah alpukat merupakan salah satu jenis buah yang digemari banyak orang karena selain rasanya yang enak, buah alpukat juga kaya antioksidan dan zat gizi (Malangngi et al., 2012). Biasanya daging buah alpukat sering dikonsumsi langsung atau diolah lagi dan bijinya dibiarkan begitu saja dikarenakan masyarakat belum tahu cara memanfaatkan biji alpukat.

Hasil produksi alpukat di Indonesia meningkat di setiap tahunnya, seperti pada tahun 2010 produksi alpukat mencapai 224.278 ton, pada tahun 2011 sebanyak 275.553 ton, serta tahun 2012 sebanyak 294.200 ton (Halimah et al., 2015). Mengingat bahwa buah alpukat baru dimanfaatkan dan diambil bagian daging buahnya, sedangkan kulit dan bijinya dibuang menjadi limbah. Biji alpukat sebagai limbah yang belum digunakan secara ekonomis, menjadi sangat potensial sebagai sumber pati. Kandungan karbohidrat tinggi yang terdapat di dalam biji alpukat, menjadikan biji alpukat ini dapat digunakan pula sebagai bahan baku pembuatan pati dari biji (Chandra et al., 2013) dan kulit biji pada alpukat yang berwarna coklat kemerahan mengandung selulosa yang dihidrolisa akan membentuk glukosa. 
Penyusun utama cadangan makanan alpukat yaitu karbohidrat. Kandungan karbohidrat pada biji alpukat cukup tinggi sehingga lebih menguntungkan jika yang diekstrak adalah pati (Chandra et al., 2013). Pati merupakan penyusun utama cadangan makanan tumbuh-tumbuhan. Pati adalah polimer D-glukosa dan ditemukan sebagai karbohidrat simpanan dalam tumbuhan. Pati terdapat sebagai butiran kecil dengan berbagai ukuran dan bentuk yang khas untuk setiap spesies tumbuhan. Pati terdiri atas dua polimer yang berlainan, senyawa rantai lurus yaitu amilosa dan komponen yang bercabang yaitu amilopektin (Lubis, 2011). Untuk mendapatkan pati dari suatu tanaman dilakukan proses ekstraksi pati yang merupakan proses memisahkan pati dari komponen lainnya yang terdapat pada biji buah alpukat. Pati yang didapatkan kemudian dihidrolisis untuk memperoleh glukosa (Chandra et al., 2013).

Masyarakat hanya mengenal bahwa produksi gula berasal dari bahan baku tebu dan jagung, padahal tidak hanya tebu dan jagung yang dapat digunakan sebagai bahan baku pembuatan gula, tetapi tumbuhan lain yang mengandung kadar pati juga dapat dihidrolisis sehingga menghasilkan gula. Reaksi hidrolisis merupakan reaksi yang terjadi antara reaktan dan air agar senyawa di dalamnya terpecah atau terurai. Proses hidrolisis pati pada dasarnya adalah pemutusan rantai polimer pati menjadi unit-unit monosakrida. Proses hidrolisis pati menjadi sirup glukosa dapat menggunakan katalis asam, enzim, atau gabungan keduanya pada waktu, suhu dan $\mathrm{pH}$ tertentu. Biasanya reaksi yang terjadi antara air dan reaktan berjalan sangat lambat sehingga diperlukan katalisator agar memperbesar keaktifannya. Katalisator yang digunakan biasanya berasal dari golongan asam kuat $\mathrm{HCl}$ dan $\mathrm{H}_{2} \mathrm{SO}_{4}$ merupakan salah satu katalisator asam kuat yang sering digunakan.

Sirup glukosa dapat digunakan sebagai bahan baku industri makanan, minuman dan farmasi. Sirup glukosa banyak digunakan sebagai pemanis pada industri pangan (Risoyatiningsih, 2011). Sirup glukosa dapat diperoleh dari bahan-bahan berpati seperti biji nangka, rebung, jagung, tapioka dan jenis umbiumbian (M.W \& Dziedzic, 2014). Di sebagian besar sirup glukosa diproduksi dari 
tanaman yang mengandung glukosa dan pati dan baru sebagian kecil dari bahan yang mengandung serat atau selulosa seperti ampas kelapa, jagung, kentang, ubi kayu, dan sagu. Di Indonesia, sirup glukosa dapat digunakan sebagai bahan baku pembuatan etanol, pembuatan selai, campuran minuman ringan dan industri permen. Seiring dengan berjalannya waktu perkembangan industri makanan yang begitu pesat hingga saat ini produksi gula dari tebu masih sangat kurang, sehingga pemerintah untuk menutupi kebutuhan masih mengimpor dari beberapa negara tetangga.

\section{Bahan dan Metode}

Bahan dan peralatan yang diperlukan dalam penelitian ini antara lain adalah biji alpukat, aquadest, HCL 3\%, $\mathrm{NaOH} 3 \%$, larutan Benedict, gelas erlenmeyer, neraca analitik, labu leher 3, oven, tabung reaksi, indikator $\mathrm{pH}$, corong, termometer, kertas saring, blender, ayakan 50 mesh, pisau, furnace, seperangkat alat hidrolisis, spatula, alat refraktometer, bunsen, kawat kasa dan kaki tiga.

Penelitian ini terdiri dari tiga tahap yaitu persiapan tepung pati biji alpukat, tahap hidrolisa tepung pati biji alpukat menggunakan asam klorida dan tahap analisa. Variasi percobaan dilakukan terhadap suhu reaksi yaitu $75 ; 85 ; 95{ }^{\circ} \mathrm{C}$ dan terhadap waktu reaksi yaitu 120;135;150;165;180 menit.

Pembuatan tepung pati biji alpukat dilakukan dengan dibersihkan terlebih dahulu biji alpukat setelahnya biji alpukat dihaluskan menggunakan blender dengan penambahan air. Kemudian dilakukan penyaringan dengan menggunakan kain saring untuk diambil pati dan pati diendapkan. Didapatkan endapan kemudian endapan dikeringkan dengan oven pada suhu $70^{\circ} \mathrm{C}$ selama 24 jam. Pati yang diperoleh kemudian diayak pada 50 mesh.

Hidrolisa tepung pati biji alpukat menggunakan asam klorida dilakukan dengan dihidrolisa tepung pati didalam labu leher tiga sebanyak 30 gram dan ditambahkan asam klorida 3\% sebanyak $150 \mathrm{ml}$. Hidrolisis dilakukan dengan variasi suhu $75 ; 85 ; 95^{\circ} \mathrm{C}$ dan waktu $120 ; 135 ; 150 ; 165 ; 180$ menit. Hasil hidrolisis dinetralkan dengan $\mathrm{NaOH} 3 \%$. 
Tahap analisa diawali dengan cara menganalisa kandungan glukosa dengan larutan Benedict. Kemudian dilakukan analisa kadar air dengan dimasukkan sampel kedalam oven selama 3 jam dan suhu $105^{\circ} \mathrm{C}$. Setelah itu dilakukan analisa kadar abu dengan dimasukkan sampel kedalam furnace selama 3 jam dan suhu $600{ }^{\circ} \mathrm{C}$. Kemudian dilakukan analisa keadaan yang meliputi kadar kemanisan, bau, dan warna.

\section{Hasil dan Diskusi}

\subsection{Pengaruh Suhu dan Waktu Hidrolisa Terhadap Kadar Glukosa}

Adapun perbandingan pengaruh suhu dan waktu hidrolisa terhadap kadar glukosa dapat dilihat pada gambar 1 dibawah ini.

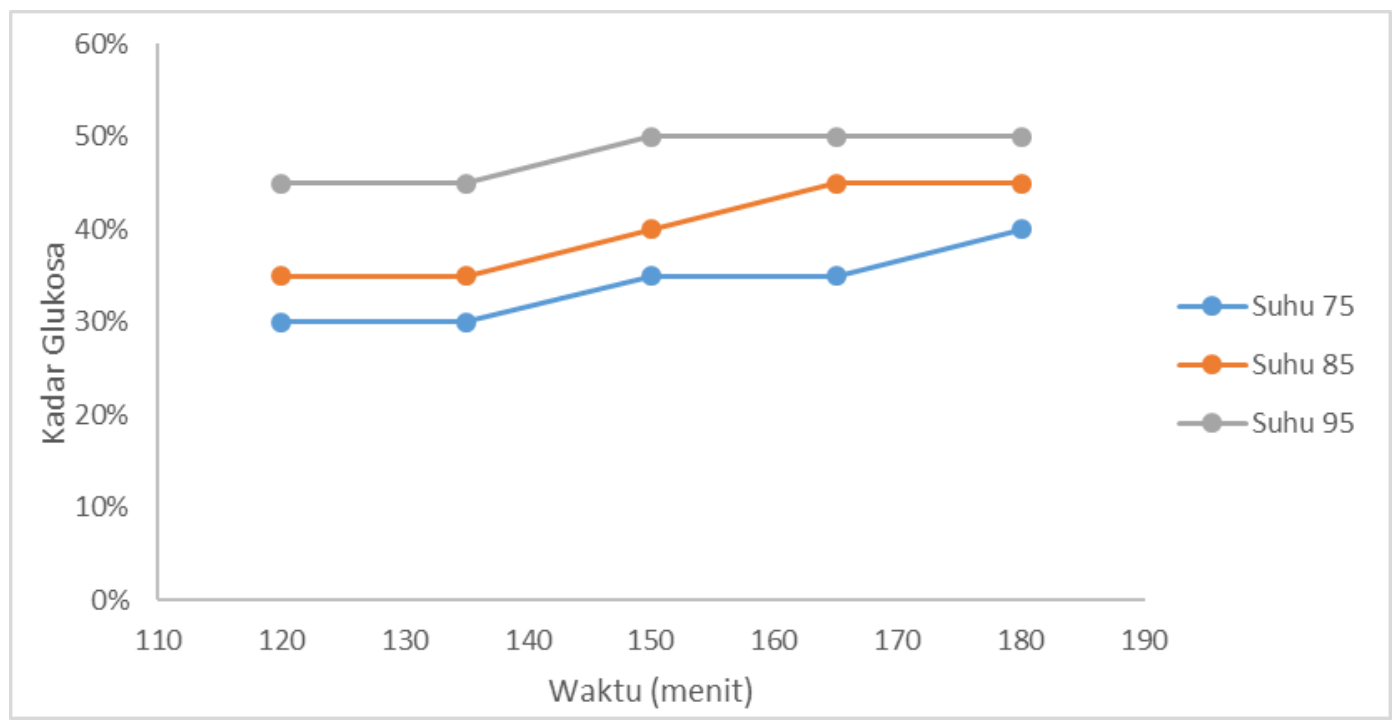

Gambar 1. Hubungan Antara Suhu dan Waktu Hidrolisa Terhadap Kadar Glukosa

Berdasarkan Gambar 1 menunjukkan bahwa kadar glukosa terendah adalah $30 \%$ pada suhu $75^{\circ} \mathrm{C}$ dan waktu 120 menit. Sedangkan kadar glukosa paling tinggi adalah sebesar $50 \%$ pada suhu $95^{\circ} \mathrm{C}$ dan waktu 180 menit. Adanya glukosa dibuktikan dengan uji benedict, dimana glukosa merupakan gula peresuksi yang dapat mereduksi senyawa logam bersifat oksidator. Hal ini karena gula pereduksi mempunyai gugus aldehida dan keton. Dalam pengujian yang dilakukan akan terbentuk endapan yang berwarna kuning, hijau atau merah bata. Warna endapan 
ini tergantung pada konsentrasi karbohidrat yang diuji (Dinarsari \& Adhitasari, 2013). Syarat mutu produksi untuk glukosa cair minimal 30\%, dari hasil penelitian yang dilakukan semua memenuhi syarat mutu glukosa cair.

Dari Gambar 1 dapat dilihat bahwa semakin tinggi suhu maka kadar glukosa yang dihasilkan juga semakin banyak karena peningkatan suhu mempercepat proses hidrolisis. Peningkatan suhu juga dapat meningkatkan laju suatu reaksi. Adanya peningkatan laju reaksi inilah yang menghasilkan kadar glukosa semakin banyak. Waktu hidrolisis yang semakin lama akan memperbanyak jumlah tumbukan zat-zat pereaksi sehingga molekul-molekul yang bereaksi semakin banyak dan memperbanyak hasil yang terbentuk seperti penelitian yang sudah dilakukan oleh (Brandberg et al., 2005).

\subsection{Pengaruh Suhu dan Waktu Reaksi Terhadap Kadar Air}

Adapun perbandingan pengaruh suhu dan waktu hidrolisa terhadap kadar air dapat dilihat pada gambar 2 dibawah ini.

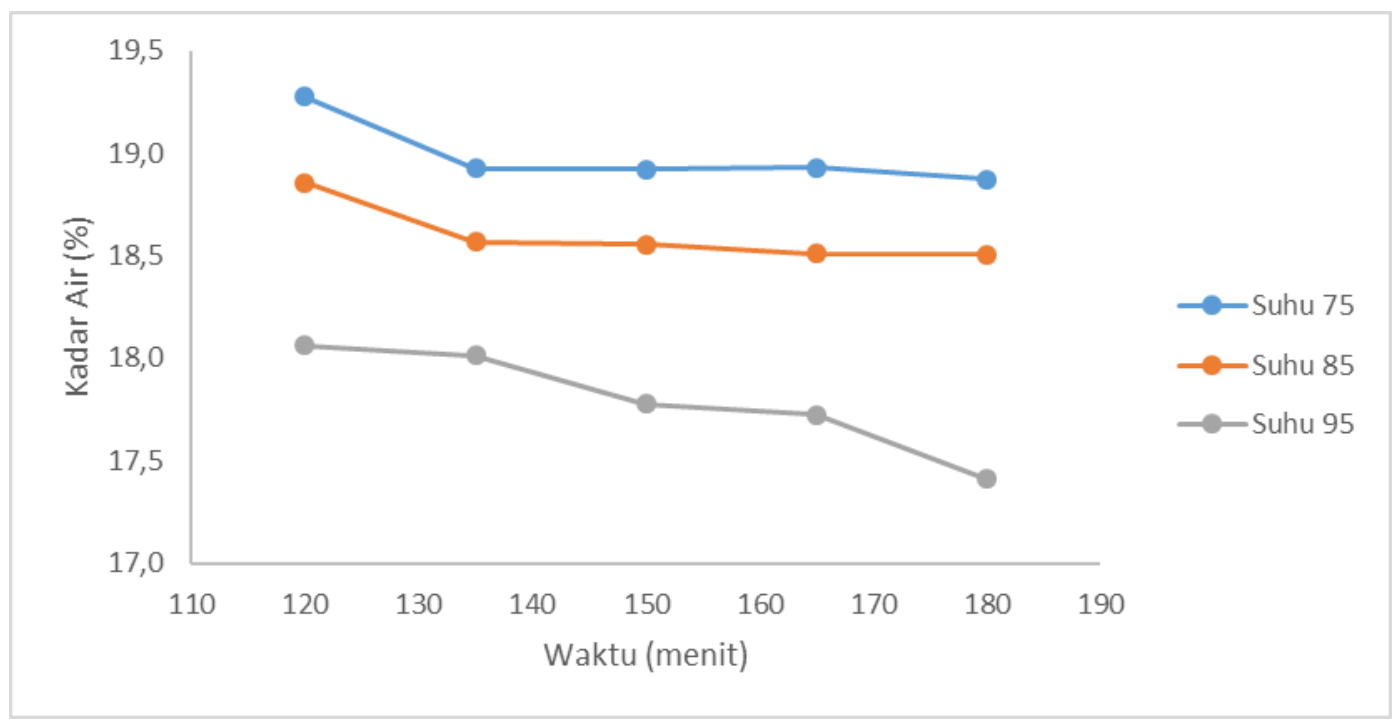

Gambar 2. Hubungan Antara Suhu dan Waktu Hidrolisa Terhadap Kadar Air

Berdasarkan Gambar 2 menunjukkan kadar air paling rendah adalah 17,4105\% pada suhu $95^{\circ} \mathrm{C}$ dan waktu 180 menit. Sedangkan kadar air paling tinggi adalah $19,2792 \%$ pada suhu $75^{\circ} \mathrm{C}$ dan waktu 120 menit. Dapat dilihat 
bahwa perbedaan temperatur dan waktu hidrolisis sangat berpengaruh terhadap kadar air dimana semakin tinggi suhu dan waktu yang digunakan maka kadar air yang terkandung akan semakin rendah. Hal ini disebabkan karena terjadi penguapan air yang semakin banyak pada suhu dan waktu hidrolisis yang semakin lama. Kadar air merupakan salah satu sifat kimia suatu bahan pangan yang berpengaruh terhadap kualitas dan lama penyimpanan bahan pangan. Kadar air yang tinggi menyebabkan mudahnya bakteri, kapang dan khamir berkembang biak. Semakin sedikit kadar air dalam glukosa cair maka semakin baik mutu glikosa cair tersebut. Syarat mutu produksi untuk kadar air maksimal 20\%, dari hasil penelitian yang dilakukan semua memenuhi syarat mutu glukosa cair.

\subsection{Pengaruh Suhu dan Waktu Hidrolisa Terhadap Kadar Abu}

Adapun perbandingan pengaruh suhu dan waktu hidrolisis terhadap kadar abu dapat dilihat pada gambar 3 dibawah ini.

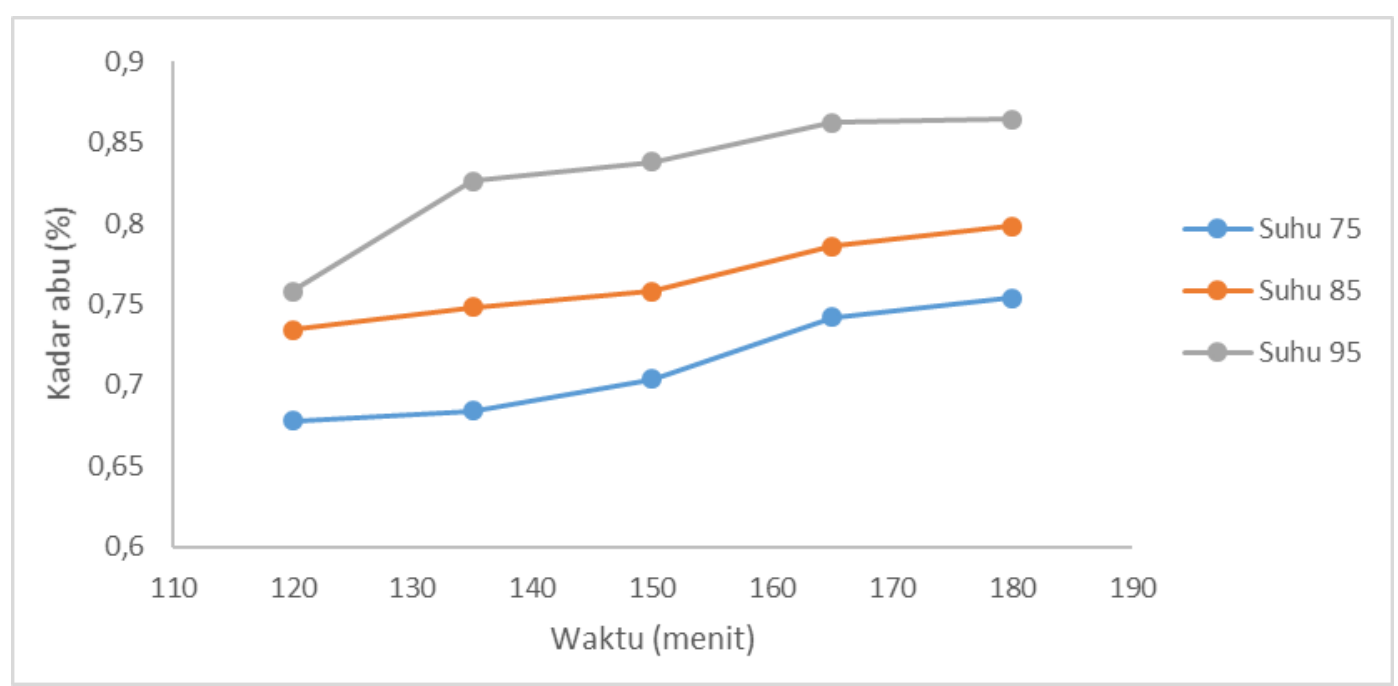

Gambar 3. Hubungan Antara Suhu dan Waktu Hidrolisa Terhadap Kadar Abu

Berdasarkan Gambar 3 menunjukkan kadar abu paling rendah adalah 0,678\% pada suhu $75^{\circ} \mathrm{C}$ dan waktu 120 menit. Sedangkan kadar abu paling tinggi adalah $0,864 \%$ pada suhu $95^{\circ} \mathrm{C}$ dan waktu 180 menit. Dapat dilihat bahwa perbedaan temperatur dan waktu hidrolisis sangat berpengaruh terhadap kadar abu 
dimana semakin tinggi suhu dan waktu yang digunakan maka kadar abu yang terkandung akan semakin tinggi juga. Hal ini disebabkan karena semakin sempurna pemecahan pati menjadi glukosa sehingga kadar abu semakin tinggi. Syarat mutu produksi untuk kadar abu maksimal 1\%, dari hasil penelitian yang dilakukan semua memenuhi syarat mutu glukosa cair.

\subsection{Pengaruh Suhu dan Waktu Hidrolisa Terhadap Analisa Keadaan}

Analisa keadaan yang meliputi analisa kadar kemanisan, warna dan bau. Adapun perbandingan pengaruh suhu dan waktu hidrolisa terhadap analisa kadar kemanisan dapat dilihat pada gambar 4 dibawah ini.

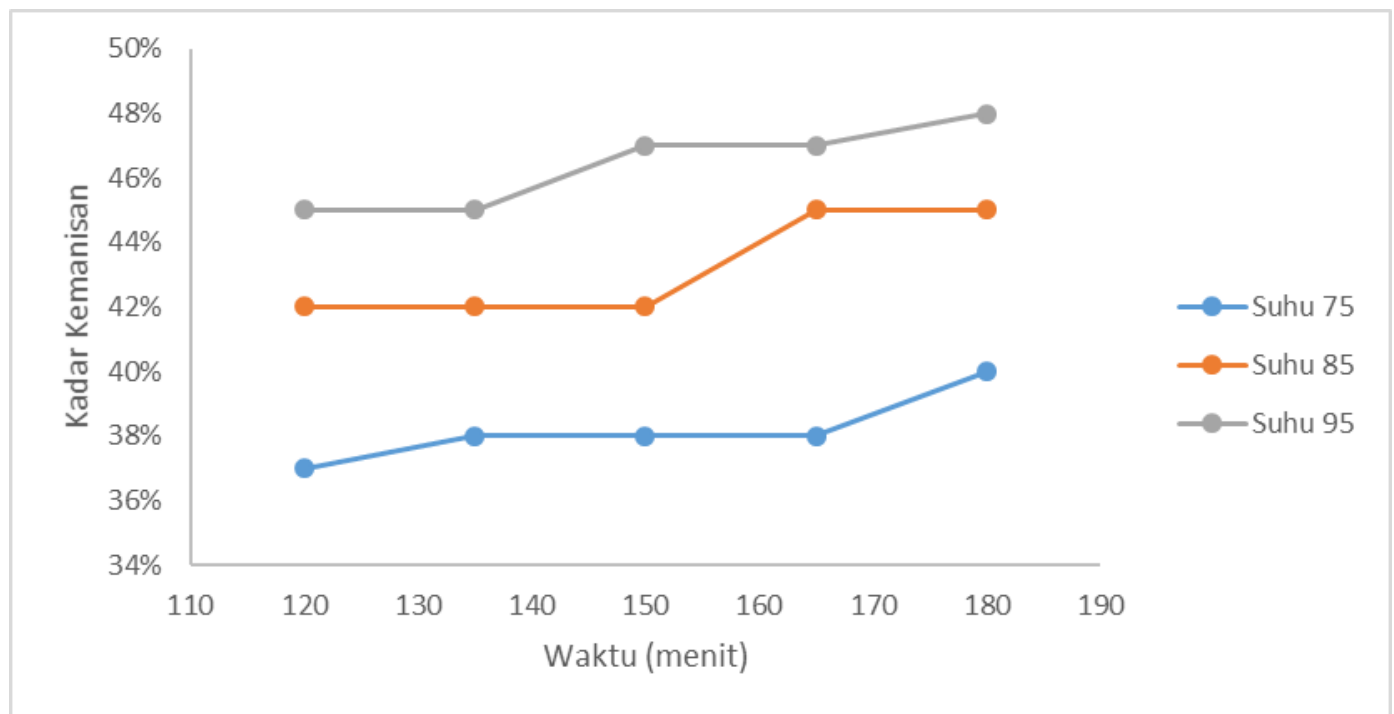

Gambar 4. Hubungan Antara Waktu dan Suhu Hidrolisa Terhadap Kadar Kemanisan

Berdasarkan Gambar 4 menunjukkan kadar kemanisan paling rendah adalah $37 \%$ pada suhu $75^{\circ} \mathrm{C}$ dan waktu 120 menit. Sedangkan kadar kemanisan paling tinggi adalah $48 \%$ pada suhu $95^{\circ} \mathrm{C}$ dan waktu 180 menit. Dapat dilihat bahwa semakin besar suhu dan waktu hidrolisa maka kadar kemanisan yang didapat akan semakin meningkat. Hal ini disebabkan oleh semakin tingginya suhu dan waktu menyebabkan kadar glukosa yang dihasilkan pada saat reaksi berlangsung semakin tinggi dan membuat tingkat kemanisan dari sirup semakin tinggi juga. 
Warna yang dihasilkan pada sirup glukosa ini yaitu berwarna kecoklatan. Warna kecoklatan ini didapatkan karena waktu pemanasan cukup lama, maka gula pun akan berubah warna menjadi kuning, kemudian kecokelatan, selanjutnya berubah warna menjadi sangat cokelat. Hasil analisis terlihat warna sirup glukosa belum memenuhi syarat mutu SNI-01-2978-1992. Untuk aroma sirup glukosa yang didapatkan tidak memiliki bau. Maka sirup glukosa yang dihasilkan sudah memenuhi syarat mutu SNI-01-2978-1992 (Richana et al., 1992).

\section{Simpulan dan Saran}

Suhu dan waktu sangat mempengaruhi banyaknya kadar glukosa yang didapatkan, glukosa paling tinggi didapat pada suhu $95^{\circ} \mathrm{C}$ dan waktu 180 menit sebesar 50\%, kadar air paling baik diperoleh pada suhu $95^{\circ} \mathrm{C}$ dan waktu 180 menit sebesar $17,4105 \%$, kadar abu paling baik diperoleh pada suhu $95^{\circ} \mathrm{C}$ dan waktu 180 menit sebesar $0,864 \%$ dan suhu dan waktu paling baik dalam pembuatan sirup glukosa ini adalah suhu $95^{\circ} \mathrm{C}$ dan waktu 180 menit.

Penelitian ini dapat dilanjutkan dengan mencoba menggunakan asam dari asam alami seperti asam jeruk atau asam belimbing dan menggunakan variable waktu dan suhu yang lebih rendah atau lebih tinggi agar didapat variasi yang berbeda.

\section{Daftar Pustaka}

1. Brandberg, T., Sanandaji, N., Gustafsson, L., \& Franzén, C. J. (2005). Continuous fermentation of undetoxified dilute acid lignocellulose hydrolysate by Saccharomyces cerevisiae ATCC 96581 using cell recirculation. Biotechnology Progress, 21(4), 1093-1101. https://doi.org/10.1021/bp050006y

2. Chandra, A., Inggrid, H. M., \& Verawati. (2013). Pengaruh pH dan Jenis Larutan Perendam pada Perolehan dan Karakterisasi Pati dari Biji Alpukat. Jurnal Lembaga Penelitian Dan Pengabdian Kepada Masyarakat Universitas Katolik Parahyangan 2013, 30-39. http://journal.unpar.ac.id/index.php/rekayasa/article/viewFile/253/238

3. Dinarsari, A. A., \& Adhitasari, A. (2013). Proses Hidrolisa Pati Talas Sente (Alocasia macrorrhiza) Menjadi Glukosa: Studi Kinetika Reaksi. Jurnal Teknologi Kimia Dan Industri, 2(4), 253-260. http://ejournal- 
s1.undip.ac.id/index.php/jtki

4. Halimah, N., Aulia, Dewi, Istiqomah, I., \& Rohmah, S. (2015). Pengolahan Limbah Biji Alpukat Untuk Pembuatan Dodol Pati Sebagai Alternatif Pengobatan Ginjal. Jurnal Ilmiah Mahasiswa Fakultas Kesehatan Masyarakat Universitas Diponegoro, 4(1), 32-37.

5. Jonathan Giovanni, F. Sinung Pranata, L. M. E. P. (2013). Variasi Waktu Dan Enzim $\alpha$ - Amilase Pada Hidrolisis Pati Sukun (Artocarpus altilis Park.). Jurnal Ilmiah Biologi, 1-11.

6. Lubis, L. M. (2011). Ekstraksi Pati dari Biji Alpukat.

7. M.W, K., \& Dziedzic, S. Z. (2014). Haudbook of Starch Hydrolysis Products aud their Derivatives.

8. Malangngi, L., Sangi, M., \& Paendong, J. (2012). Penentuan Kandungan Tanin dan Uji Aktivitas Antioksidan Ekstrak Biji Buah Alpukat (Persea americana Mill.). Jurnal MIPA, $1(1), \quad 5$. https://doi.org/10.35799/jm.1.1.2012.423

9. Richana, N., Budhiyanto, A., \& Arief, R. . (1992). bab_IV_e-1.pdf.

10. Risoyatiningsih, S. (2011). Hidrolisis pati ubi jalar kuning menjadi glukosa secara enzima. Jurnal Teknik Kimia, 5(2), 417-424. 